University of Nebraska - Lincoln

DigitalCommons@University of Nebraska - Lincoln

$12-1-2006$

\title{
NESTING SUCCESS OF GRASSLAND AND SAVANNA BIRDS ON RECLAIMED SURFACE COAL MINES OF THE MIDWESTERN UNITED STATES
}

\author{
Edward W. Galligan \\ Indiana State University \\ Travis L. DeVault \\ Purdue University, Travis.L.DeVault@aphis.usda.gov \\ Steven L. Lima \\ Indiana State University, slima@indstate.edu
}

Follow this and additional works at: https://digitalcommons.unl.edu/icwdm_usdanwrc

Part of the Environmental Sciences Commons

\begin{abstract}
Galligan, Edward W.; DeVault, Travis L.; and Lima, Steven L., "NESTING SUCCESS OF GRASSLAND AND SAVANNA BIRDS ON RECLAIMED SURFACE COAL MINES OF THE MIDWESTERN UNITED STATES" (2006). USDA National Wildlife Research Center - Staff Publications. 630.

https://digitalcommons.unl.edu/icwdm_usdanwrc/630
\end{abstract}

This Article is brought to you for free and open access by the U.S. Department of Agriculture: Animal and Plant Health Inspection Service at DigitalCommons@University of Nebraska - Lincoln. It has been accepted for inclusion in USDA National Wildlife Research Center - Staff Publications by an authorized administrator of DigitalCommons@University of Nebraska - Lincoln. 


\title{
NESTING SUCCESS OF GRASSLAND AND SAVANNA BIRDS ON RECLAIMED SURFACE COAL MINES OF THE MIDWESTERN UNITED STATES
}

\author{
EDWARD W. GALLIGAN, ${ }^{1,3}$ TRAVIS L. DEVAULT, ${ }^{2,4}$ AND STEVEN L. LIMA ${ }^{1,5}$
}

\begin{abstract}
Reclaimed surface coal mines in southwestern Indiana support many grassland and shrub/ savanna bird species of conservation concern. We examined the nesting success of birds on these reclaimed mines to assess whether such "unnatural" places represent productive breeding habitats for such species. We established eight study sites on two large, grassland-dominated mines in southwestern Indiana and classified them into three categories (open grassland, shrub/savanna, and a mixture of grassland and shrub/savanna) based on broad vegetation and landscape characteristics. During the 1999 and 2000 breeding seasons, we found and monitored 911 nests of 31 species. Daily nest survival for the most commonly monitored grassland species ranged from 0.903 (Dickcissel, Spiza americana) to 0.961 (Grasshopper Sparrow, Ammodramus savannarum). Daily survival estimates for the dominant shrub/savanna nesting species ranged from 0.932 (Brown Thrasher, Toxostoma rufum) to 0.982 (Willow Flycatcher, Empidonax traillii). Vegetation and landscape effects on nesting success were minimal, and only Eastern Meadowlarks (Sturnella magna) showed a clear time-of-season effect, with greater nesting success in the first half of the breeding season. Rates of Brown-headed Cowbird (Molothrus ater) parasitism were only $2.1 \%$ for grassland species and $12.0 \%$ for shrub/savanna species. The nesting success of birds on reclaimed mine sites was comparable to that in other habitats, indicating that reclaimed habitats on surface mines do not necessarily represent reproductive traps for birds. Received 1 August 2005, accepted 10 April 2006.
\end{abstract}

Several bird species have benefited in recent decades from the reclamation of surface coal mines in the midwestern United States (Bajema et al. 2001, DeVault et al. 2002, Ingold 2002). The Surface Mining Reclamation Act of 1977 and earlier laws led (perhaps unintentionally) to mine reclamation techniques that favored the production of grasslands rather than forested habitats (Brothers 1990), resulting in hundreds of $\mathrm{km}^{2}$ of newly created grasslands. These "mine grasslands" harbor a diverse assemblage of grassland birds, many of which are of management concern at state and federal levels. Recent studies in southwestern Indiana, covering 19 reclaimed mines, suggest that populations of key grassland bird species, such as Grasshopper (Ammodramus savannarum) and Henslow's (A. henslowii) sparrows, are quite large (Bajema et al. 2001, DeVault et al. 2002). Reclaimed mines also

${ }^{1}$ Dept. of Ecology and Organismal Biology, Indiana State Univ., Terre Haute, IN 47809, USA.

${ }^{2}$ Dept. of Forestry and Natural Resources, Purdue Univ., West Lafayette, IN 47907, USA.

${ }^{3}$ Current address: Louisville Metro Health Dept., 400 E. Gray St., Louisville, KY 40202, USA.

${ }^{4}$ Current address: U.S. Dept. of Agriculture, Wildlife Services, National Wildlife Research Center, 5757 Sneller Rd., Brewerton, NY 13029, USA.

${ }^{5}$ Corresponding author; e-mail: slima@indstate.edu contain scattered trees (from plantings and natural succession) that approximate the structure of savanna habitat to a substantial degree (Scott et al. 2002, Scott and Lima 2004). Accordingly, these reclaimed mines harbor several savanna bird species (DeVault et al. 2002) of conservation concern (Davis et al. 2000, Hunter et al. 2001).

The size of reclaimed mines in the midwestern United States is one of their most important characteristics-several exceed 2,000 ha (Bajema and Lima 2001, Ingold 2002). Many grassland bird species appear to be "area sensitive" in that usually they are found only in grassland fragments of a given size or greater (Herkert 1994, Walk and Warner 1999, Winter and Faaborg 1999; but see Horn et al. 2000, Johnson and Igl 2001). Most studies suggest that grasslands $>50-100$ ha should contain a full complement of grassland passerines. Virtually all grasslands on reclaimed mines in southwestern Indiana are $>100$ ha (Bajema and Lima 2001). Furthermore, small grassland size may be associated with poor nesting success, reflecting the close proximity of habitat edge, which can lead to greater predator densities (Winter et al. 2000, Herkert et al. 2003) and greater rates of Brown-headed Cowbird (Molothrus ater) parasitism (Johnson 
and Temple 1990). These effects of habitat size are similar to those documented for many forest-nesting passerines (e.g., Donovan et al. 1995, Robinson et al. 1995).

Even though large reclaimed coal mines in the Midwest harbor a variety of breeding bird species, they are decidedly unnatural places in terms of vegetation (Scott and Lima 2004). Hence, it is conceivable that reclaimed mines function as giant ecological "traps" that divert breeding birds away from more productive habitats (sensu Gates and Gysel 1978). Even though grassland birds can breed successfully in non-native grasslands (e.g., Warner 1994, Best et al. 1997, Kershner and Bollinger 1998, Robb et al. 1998, Ingold 2002, Monroe and Ritchison 2005), the possibility that they represent ecological traps is not trivial. For example, reclaimed midwestern mines often are dominated by tall fescue (Festuca arundinacea; Scott et al. 2002, Scott and Lima 2004), which often is infected with a symbiotic fungal endophyte (Neotyphodium coenophialum). Such infected fescue is associated with declines in plant diversity and lowered reproductive success of herbivores (vertebrate and invertebrate; Clay and Holah 1999). Tall fescue might reduce insect production and render reclaimed mine grasslands into poor breeding habitat. Although tall fescue also may affect the breeding prospects of savanna bird species, they might be less affected than their grassland counterparts.

There are few data available for assessing whether birds inhabiting reclaimed surface mines are nesting successfully. Thus, our goal in this study was to investigate patterns of avian nesting success within reclaimed surface coal mines, with the larger goal of evaluating whether reclaimed mines provide productive breeding habitats for grassland and savanna birds.

\section{METHODS}

Study sites.-Our work spanned the 1999 and 2000 breeding seasons. In both years, field work began in late April and continued through the 1st week of August. Study sites were established at two large reclaimed surface coal mines in west-central Indiana within $30 \mathrm{~km}$ of the city of Terre Haute. Four sites were established at the Chinook Mine $\left(39^{\circ}\right.$ $\left.28^{\prime} \mathrm{N}, 87^{\circ} 13^{\prime} \mathrm{W} ; 2,000 \mathrm{ha}\right)$ in Clay and Vigo counties and four were established at the Universal Mine $\left(39^{\circ} 36^{\prime} \mathrm{N}, 87^{\circ} 28^{\prime} \mathrm{W}\right.$; 3,450 ha) in southern Vermillion County. The Chinook sites ranged in size from 39 to 67 ha, whereas the Universal sites were smaller (12 to $38 \mathrm{ha}$ ) due to constraints imposed by cattle and haying operations. Chinook Mine comprised $61 \%$ undisturbed grassland and $18 \%$ hayfields; the remaining $21 \%$ comprised relatively even percentages of wetlands, row crops, and forests (Bajema and Lima 2001). Universal Mine was $33 \%$ undisturbed grassland and $43 \%$ hayfields and cattle pastures, with the remaining $24 \%$ split about evenly between forest and lakes/ wetlands (Bajema and Lima 2001).

Study sites were chosen to represent the range of grassland-dominated habitats found in the reclaimed surface coal mines of southwestern Indiana. Two study sites (one in each mine) were classified as "open grassland." We defined open grassland sites as relatively undisturbed areas (no mowing for $\geq 2$ years, usually many more) that were dominated by grasses $(>95 \%$, by area), with some forbs and very few saplings, trees, or shrubs (Scott et al. 2002). Open grasslands represented the most abundant habitat type found on most reclaimed surface mines (Bajema and Lima 2001). Nests found in these open sites were, on average, $760 \mathrm{~m}$ from the nearest mature forest habitat, with many nests well over $1,000 \mathrm{~m}$ from forest.

Three study areas were classified as "shrub/ savanna" sites (one at Chinook Mine and two at Universal Mine). We defined shrub/savanna sites as predominantly grassy habitats with many scattered young trees (4-8 m high, generally open canopy) and shrubs, often representing a transition zone between grassland and forested areas. Small groves of trees also were associated with small wetland areas. Black locusts (Robinia pseudoacacia) dominated in shrub/savanna sites, although significant numbers of oaks (Quercus spp.), eastern cottonwoods (Populus deltoides), and mature autumn olives (Elaeagnus umbellata) were found in some areas. "Shrubby" species included young saplings of these tree species, along with hawthorn (Crataegus spp.) and multiflora rose bushes (Rosa multiflora). Shrub/savanna sites were adjacent to mature forest (and hence were mainly on the edges of the reclaimed mines). The average distance 
between nests found on shrub/savanna sites and the forest edge was $240 \mathrm{~m}$. Shrub/savanna sites contained significant $(30-60 \%$, by area) open grassland habitat.

Finally, we designated the remaining three study sites (two at Chinook Mine and one at Universal Mine) as "mixed" sites. Mixed sites were defined as mostly open grassland habitat with a few areas of significant shrub/ savanna habitat. In general, these sites were $70-80 \%$ open grassland. The average distance between nests found on mixed sites and the nearest mature forest habitat was $430 \mathrm{~m}$.

Nest location and monitoring.-Nest searches were conducted daily in 1999 and 2000 from early morning until early afternoon by a team of three to five field workers. Nests were detected by (1) rope dragging, (2) following adults that were carrying food and nesting material, and (3) systematic searches of likely nesting sites (Martin and Geupel 1993). During the 2000 field season, we also used a thermographic imager to aid in nest detection (Galligan et al. 2003).

When a nest was located, a small colored flag was placed $10 \mathrm{~m}$ to the north of it and a small piece of colored tape was tied to vegetation $5 \mathrm{~m}$ south of the nest (Picozzi 1975, Walk 2001). The accurate alignment of flag, tape, and nest allowed workers to relocate nests quickly with minimal disturbance. Species associated with each nest were identified, and nests were checked only every 3 to 4 days to minimize disturbance (Bart 1977). During each nest check, we recorded the presence or absence of adults, the number of eggs or chicks, and, if appropriate, the developmental stage of the chicks. We also recorded indicators of nestling mortality or cowbird parasitism.

Vegetation and landscape variables.-We gathered basic information on the physical relationships between nests, the surrounding vegetation, and major landscape features; however, we limited analyses of these variables to grassland bird species, whose nests were located in greater numbers than savanna species. For each nest, we recorded height above ground, species and height of the vegetation in which it was placed, dominant vegetation and vegetation height within $1 \mathrm{~m}$ of the nest, litter depth at the nest, percent cover of litter within $1 \mathrm{~m}$ of the nest, distance to the nearest forest edge, and distance to the nearest tree ( $>1 \mathrm{~m}$ high). We used GPS units to record the location of all nests and to delineate nearby forested areas.

Data analyses.-We estimated the daily probability of nest survival (DNS) for each species according to the Mayfield method (Mayfield 1961, 1975). We assumed that any relevant nesting event (e.g., hatching, failure, fledging) occurred at the midpoint of the interval between nest visits. A nest was considered successful when it fledged one or more young (Mayfield 1961, 1975).

Our analyses were limited primarily to univariate tests of vegetation, landscape, and temporal variable effects on DNS or the fate of individual nests (success or failure). We tested for interactions only for study site and time of season. We compared DNS estimates across categorical variables (i.e., among years, sites, and different habitat types) by using CONTRAST (Hines and Sauer 1989). CONTRAST uses a generalized $\chi^{2}$ statistic that allows multiple comparisons of survival rates from different time periods or study areas (Sauer and Williams 1989). We compared DNS among years and sites for all species listed in Table 1. Because we found large numbers of Field Sparrow (Spizella pusilla), Ammodramus spp. (Henslow's and Grasshopper sparrows, combined), Dickcissel (Spiza americana), Red-winged Blackbird (Agelaius phoeniceus), and Eastern Meadowlark (Sturnella magna) nests, we were able to examine DNS trends within breeding seasons (comparing DNS between the first and second halves of the breeding seasons) and between habitat types for these species. We used logistic regression, with the fate of individual nests (failure or success) as the dependent variable, to evaluate the effects of various continuous landscape and vegetation variables on nesting success (SPSS, Norušis 1993). Our analyses were applied primarily to habitat types (open, mixed, and shrub/savanna) because they were distinctly different from the surrounding landscape characteristics. For a given habitat type, we limited our analyses to those species for which we had adequate numbers of nest-days (see grassland species listed in Table 1). The effects of various factors on nest survival were analyzed individually, except as noted. Results are presented as means and standard 
TABLE 1. Daily nest survival (DNS) for bird species inhabiting grassland and shrub/savanna on reclaimed coal mines in Indiana during 1999 and 2000.

\begin{tabular}{|c|c|c|c|c|}
\hline & $n$ (no. successful) & $\mathrm{ND}^{\mathrm{a}}$ & DNS & $\mathrm{SE}$ \\
\hline \multicolumn{5}{|l|}{ Grassland species } \\
\hline Grasshopper Sparrow & $41(26)$ & 383 & 0.961 & 0.010 \\
\hline Henslow’s Sparrow & $21(9)$ & 236 & 0.949 & 0.014 \\
\hline Field Sparrow & $90(36)$ & 629 & 0.919 & 0.011 \\
\hline Dickcissel & $47(11)$ & 369 & 0.903 & 0.016 \\
\hline Eastern Meadowlark & $129(58)$ & 1450 & 0.951 & 0.006 \\
\hline Red-winged Blackbird & $264(74)$ & 2439 & 0.923 & 0.005 \\
\hline \multicolumn{5}{|l|}{ Shrub/Savanna species } \\
\hline Mourning Dove & $62(33)$ & 816 & 0.962 & 0.007 \\
\hline Willow Flycatcher & $30(22)$ & 440 & 0.982 & 0.006 \\
\hline American Robin & $33(12)$ & 313 & 0.933 & 0.014 \\
\hline Brown Thrasher & $31(14)$ & 251 & 0.932 & 0.016 \\
\hline Yellow Warbler & $21(13)$ & 272 & 0.971 & 0.010 \\
\hline
\end{tabular}

${ }^{a}$ Number of nest-days observed.

errors; the level of significance was set at 0.05 .

\section{RESULTS}

During our 2-year study, we found 911 active nests of 31 species. Of these nests, 465 and 446 were found at the Chinook and Universal mines, respectively. Red-winged Blackbirds, Eastern Meadowlarks, Field Sparrows, Dickcissels, Grasshopper Sparrows, and Henslow's Sparrows were (in that order) the best represented grassland birds (Table 1). Nests of other grassland species, such as those of Ringnecked Pheasants (Phasianus colchicus), Sedge Wrens (Cistothorus platensis), and Bobolinks (Dolichonyx oryzivorus), were too few in number for analyses, as these species are relatively rare on the reclaimed surface mines (DeVault et al. 2002). Among the shrub/savanna species, nests of Mourning Doves (Zenaida macroura), Willow Flycatchers (Empidonax traillii), American Robins (Turdus migratorius), and Brown Thrashers (Toxostoma rufum) were found most frequently (Table 1). The nests of other savanna species were located in numbers too small for analyses, including those of Eastern Kingbird (Tyrannus tyrannus), Bell's Vireo (Vireo bellii), Song Sparrow (Melospiza melodia), Blue Grosbeak (Passerina caerulea), Indigo Bunting (Passerina cyanea), Orchard Oriole (Icterus spurius), and American Goldfinch (Carduelis tristis).
Daily probability of nest survival: overall estimates. - The overall estimates of DNS (all data pooled) showed considerable interspecific variation. Among grassland species (Table 1), we estimated relatively high rates of DNS (near 0.950) for Grasshopper Sparrows, Henslow's Sparrows, and Eastern Meadowlarks. Conversely, we estimated DNS of $<0.925$ for Dickcissels (the lowest: 0.903), Field Sparrows, and Red-winged Blackbirds. Among savanna species, Willow Flycatchers and Yellow Warblers (Dendroica petechia) experienced the greatest DNS (0.982 and 0.971, respectively); we also estimated a high DNS for Mourning Doves (0.962), and our DNS estimate for Brown Thrasher was the lowest (0.932).

Predation accounted for the vast majority of nest failures. In most cases, we could only guess at the identity of the predators involved because many predators do not leave conclusive evidence of their identities at depredated nests (Thompson et al. 1999, Maier and DeGraaf 2000, Pietz and Granfors 2000, Burhans et al. 2002). However, many snakes were encountered during nest searches, mainly racers (Coluber constrictor) and black rat snakes (Elaphe obsoleta obsoleta); we also encountered smaller numbers of garter snakes (Thamnophis spp.) and prairie kingsnakes (Lampropeltis calligaster). Snakes were observed consuming eggs or chicks on two occasions. Only Red-winged Blackbirds appeared to suffer any 
TABLE 2. Daily nest survival (DNS) for grassland birds, by site type (open grassland, mixed, and shrub/ savanna), on reclaimed coal mines in Indiana during 1999 and 2000; $\chi^{2}$ statistics were determined using program CONTRAST.

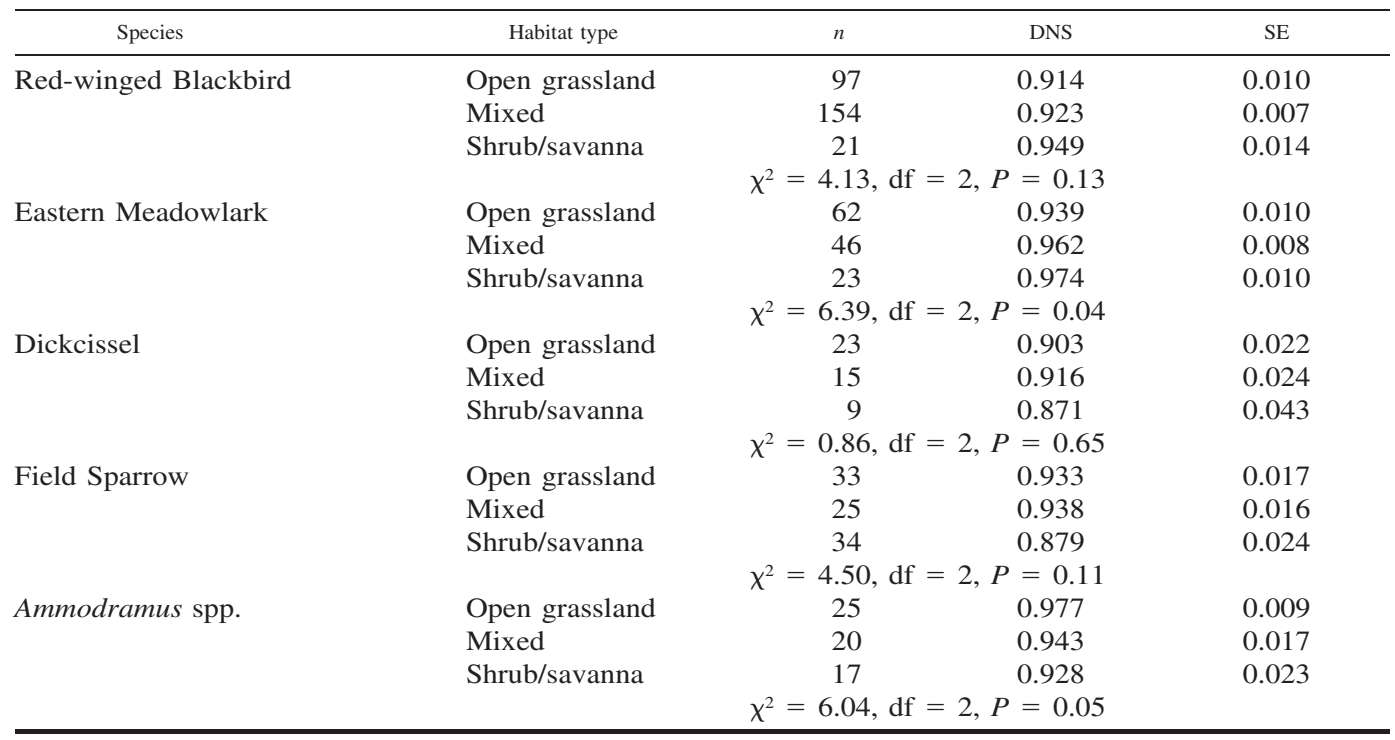

weather-induced mortality (nests blown over during severe thunderstorms), and then only early in the 1999 breeding season. There were no indications of significant nutritional stress among any nestlings.

Effects of time and site.-DNS estimates (all sites pooled) did not differ between years $\left(\chi^{2}\right.$ : all $P$ values $\left.>0.10\right)$ for any grassland or savanna species except Brown Thrasher $\left(\chi^{2}=\right.$ 5.70, df $=1, P=0.017)$. Brown Thrasher DNS was very low in 1999 (0.895 \pm 0.027$)$, but was much greater in 2000 (0.969 \pm 0.015). For American Robin, there was a similar across-year trend $\left(\chi^{2}=3.22\right.$, df $=1, P=$ 0.072 ) in DNS, which increased from 0.885 \pm 0.034 to $0.951 \pm 0.014$.

We found a significant time-of-season effect only for Eastern Meadowlarks; in both years, our estimate of their DNS was substantially greater during the first half of the breeding season than in the second half. In 1999, their DNS decreased from $0.974 \pm 0.008$ to $0.919 \pm 0.016\left(\chi^{2}=9.45, \mathrm{df}=1, P=0.005\right)$ and, in 2000 , from $0.966 \pm 0.009$ to $0.934 \pm$ $0.014\left(\chi^{2}=3.70\right.$, df $\left.=1, P=0.051\right)$. When the data were pooled across years, DNS in the first and second half of the breeding season differed substantially $(0.970 \pm 0.006$ versus
$0.926 \pm 0.011$, respectively; $\chi^{2}=12.33, \mathrm{df}=$ $1, P<0.001)$.

Significant differences in DNS also were observed across habitat types (Table 2). DNS for Eastern Meadowlarks was greatest in shrub/savanna habitat (0.974) and lowest in the open habitats $\left(0.939 ; \chi^{2}=6.39\right.$, df $=2$, $P=0.041)$. DNS of Ammodramus sparrows was higher in the increasingly open habitats $\left(\chi^{2}=6.04\right.$, df $\left.=1, P=0.050\right)$. For Field Sparrows, our DNS estimates tended to be lower in the shrub/savanna habitats $\left(\chi^{2}=\right.$ 4.508 , df $=1, P=0.11)$. DNS for Dickcissels also was lowest in the shrub/savanna habitat (0.871), but not significantly so. Logistic regression analyses of these data produced very similar results, indicating no significant interactions between habitat type and time of season, for any of the species listed in Table 2 (Wald $\chi^{2}$ tests: all $\left.P>0.50\right)$. DNS did not differ between mines $\left(\chi^{2}\right.$ : all $P>0.10$; pooling data across all study sites within a given mine) for any species listed in Table 1 .

Effects of vegetation and landscape variables.-Our analyses indicated few significant associations between DNS and vegetation or landscape features. However, DNS for Eastern Meadowlarks increased with distance to forest 
in the shrub/savanna sites (logistic regression: $\mathrm{b}=0.019$, Wald $\chi^{2}=3.95$, df $=1, P=$ 0.047). Increasing nest height also was associated with lower DNS for Field Sparrows, but only in open grassland habitats $(\mathrm{b}=-0.487$, Wald $\chi^{2}=4.22$, df $=1, P=0.040$ ); DNS was lower for nests in low shrubs than for those on the ground. For Red-winged Blackbirds, height of vegetation in which the nest was placed was positively associated with nesting success, but only in the mixed habitat type $\left(\mathrm{b}=0.051\right.$, Wald $\chi^{2}=6.42$, $\mathrm{df}=1, P$ $=0.011$ ). Finally, for Grasshopper Sparrows, height of the dominant vegetation within $1 \mathrm{~m}$ of the nest was positively associated with nesting success, but only when the data were pooled across all habitat types $(\mathrm{b}=0.465$, Wald $\chi^{2}=4.14$, df $\left.=1, P=0.046\right)$. It is notable that tall fescue (either as the vegetation in which the nest was placed or as the dominant vegetation within $1 \mathrm{~m}$ of the nest) was not significantly associated with the DNS of any focal species.

Brood parasitism.-Relatively low rates of brood parasitism by Brown-headed Cowbirds were observed during our 2-year study. Overall, only $2.1 \%$ of grassland bird nests were parasitized by cowbirds (Table 3 ). Field Sparrows were the most heavily parasitized (6.4\%), whereas we observed no parasitism on Henslow's Sparrows or Eastern Meadowlarks. Furthermore, of the 263 Red-winged Blackbird nests that we found, only four were parasitized. Shrub/savanna species as a group (including all species monitored) suffered a greater frequency of brood parasitism (12.0\%; Table 3). Of the savanna species, Orchard Orioles and Blue Grosbeaks were most heavily parasitized.

\section{DISCUSSION}

Daily nest survival.-Overall estimates of DNS varied considerably across species. In general, shrub/savanna birds experienced greater rates of DNS than grassland birds (Table 1). Among grassland birds, Eastern Meadowlarks, Grasshopper Sparrows, and Henslow's Sparrows experienced relatively high rates of DNS, whereas Dickcissels, Field Sparrows, and Red-winged Blackbirds experienced lower rates of DNS. Among shrub/savanna species, Mourning Doves, Willow Flycatchers, and Yellow Warblers experienced
TABLE 3. Brown-headed Cowbird parasitism of host species was infrequent on reclaimed coal mines in Indiana during 1999 and 2000.

\begin{tabular}{lrcr}
\hline \multicolumn{1}{c}{ Species $^{\mathrm{a}}$} & $n$ & $\begin{array}{c}\text { No. } \\
\text { Parasitized }\end{array}$ & \multicolumn{1}{c}{$\%$} \\
\hline Grassland & & & \\
Sedge Wren & 1 & 0 & 0.0 \\
Red-winged Blackbird & 263 & 4 & 1.5 \\
Bobolink & 1 & 0 & 0.0 \\
Eastern Meadowlark & 131 & 0 & 0.0 \\
Dickcissel & 47 & 2 & 4.1 \\
Field Sparrow & 93 & 6 & 6.4 \\
Grasshopper Sparrow & 41 & 1 & 2.4 \\
Henslow's Sparrow & 21 & 0 & 0.0 \\
Total & 607 & 13 & 2.1 \\
Shrub/Savanna & & & \\
Eastern Kingbird & 9 & 1 & 11.1 \\
Willow Flycatcher & 30 & 0 & 0.0 \\
Bell's Vireo & 6 & 1 & 16.7 \\
Yellow Warbler & 21 & 3 & 14.3 \\
Orchard Oriole & 10 & 4 & 40.0 \\
Blue Grosbeak & 6 & 2 & 33.3 \\
Indigo Bunting & 4 & 0 & 0.0 \\
American Goldfinch & 6 & 0 & 0.0 \\
Song Sparrow & 8 & 1 & 12.5 \\
Total & 100 & 12 & 12.0 \\
\hline
\end{tabular}

${ }^{a}$ Known egg rejectors (e.g., American Robins, Brown Thrashers) an unsuitable cowbird hosts (e.g., Mourning Doves) were not included.

relatively high rates of DNS, whereas American Robins and Brown Thrashers experienced relatively low rates of DNS. There were no significant differences in DNS across the two mines studied, despite the fact that these mines encompass the range of land-use patterns found within mines (Bajema and Lima 2001). There also were few significant differences in DNS across the two breeding seasons, despite the fact that the first season (1999) was relatively hot and dry, and the second season (2000) was cool and wet (only Brown Thrashers and American Robins had markedly greater DNS in 2000 than 1999). Thus, the general patterns apparent in Table 1 may be representative of the long-term situations faced by birds on the reclaimed mines of southwestern Indiana.

Ultimately, the variation that we observed in DNS was due to variation in nest predation, the primary cause of nest failure. Among grassland birds, it appears that open-cup, above-ground nesters, such as Field Sparrows, Dickcissels, and Red-winged Blackbirds, suffered greater predation rates than ground-nest- 
ing species (Eastern Meadowlarks and Ammodramus sparrows; Table 1). During both field seasons, we estimated greater DNS for Eastern Meadowlarks during the first half of the breeding season than during the second half. This time-of-season effect may reflect the fact that Eastern Meadowlarks began nesting in April before snakes became fully active. No other temporal patterns in DNS were apparent among other grassland species.

Open-cup nesting was not uniformly associated with greater rates of nest predation, because all shrub/savanna species in this study are open-cup nesters, and many experienced high rates of DNS (Table 1). The relatively low rate of nesting success among American Robins and Brown Thrashers was due to extremely high levels of nest predation during 1999 (which was not observed in 2000). Why only these two species experienced different levels of predation across years is not clear; however, because robins and thrashers nested in very similar sites in the shrub/savanna habitat (interior portions of larger trees), they likely experienced the same change in the predatory environment across years.

Significant associations between DNS and various vegetation and landscape-level features were few, and provided relatively little insight into the predation processes that influenced DNS. We note, however, that for many species we located too few nests for our analyses to detect subtle effects. Regardless, the significant increase in DNS with increasing distance from the forest-exhibited only in Eastern Meadowlarks in the shrub/savanna habitat-was consistent with the results of other studies (e.g., Johnson and Temple 1990) that implicated forest-edge predators as major agents of nest failure (recall that our shrub/ savanna sites were adjacent to forested habitat). The lack of an effect of distance-to-forest in the open grassland and mixed study sites may reflect the relative isolation of these sites from forested habitat ( $c f$. Paton 1994). The relatively high rates of DNS for Ammodramus sparrows in the open grassland habitats (Table 2) also may reflect the isolation from forested habitat. Nevertheless, there was no association between distance-to-forest and DNS for any other species in the shrub-savanna sites. Furthermore, the overall nesting success of Eastern Meadowlarks was actually greater in the shrub/savanna habitat than elsewhere (Table 2).

Across studies, a consistent picture of the effects of vegetation and landscape variables on nesting success of many grassland species has yet to emerge. For example, Johnson and Temple (1990) observed increased nest predation for grassland passerines when their nests were located near wooded edges. Winter et al. (2000) found that, for artificial nests, fragment size and vegetation characteristics were better predictors of survival than distance to habitat edge; however, Henslow's Sparrow nests placed within $50 \mathrm{~m}$ of an edge were not as successful as those at greater distances from forest edge. For Dickcissels, distance to habitat edge also appeared to have little effect on daily survival in prairie habitats (Hughes et al. 1999, Winter et al. 2000). Burhans et al. (2002) observed that Field Sparrows nesting in old fields had greater success when nest height was $>3 \mathrm{~m}$ above ground; however, Best (1978) suggested that Field Sparrows were more successful when nests were near the ground or in relatively tall vegetation. Pribil (1998) did not detect a relationship between nest success and vegetation features for Red-winged Blackbirds.

Brood parasitism.-Brood parasitism was minimal in our focal species, especially when compared with the high frequency of parasitism reported in midwestern forest fragments (e.g., Robinson et al. 1995). For grassland birds, only $2.1 \%$ of nests were parasitized. The frequency of parasitism for Red-winged Blackbirds at our reclaimed surface coal mines $(1.5 \%)$ markedly contrasts with the parasitism frequency of $\geq 30 \%$ for this species in other habitats and areas to the west of our study sites (Yasukawa and Searcy 1995, Clotfelter and Yasukawa 1999). Kershner (2001) and Walk (2001) reported similarly low frequency of parasitism for grassland birds nesting in restored prairies in nearby eastern Illinois (see also Robinson and Herkert 1997, Kershner and Bollinger 1998). Perhaps the frequency of grassland bird parasitism is generally greater well to the west of Indiana (Johnson and Temple 1990, Zimmerman 1993, Davis 2003; but see Winter 1999, Winter et al. 2004). In any case, the low frequency of cowbird parasitism for grassland birds of western Indiana and eastern Illinois supports 
TABLE 4. Daily nest survival for grassland birds on reclaimed coal mines in Indiana during 1999 and 2000 was similar to that recorded at other midwestern grassland sites.

\begin{tabular}{|c|c|c|c|c|c|c|}
\hline Species & $\begin{array}{l}\text { Kansas CRP } \\
\text { fields }^{\mathrm{a}}\end{array}$ & $\begin{array}{l}\text { Prairie } \\
(\mathrm{MO})^{\mathrm{b}}\end{array}$ & $\begin{array}{l}\text { Big Oaks } \\
\text { NWR (IN) }\end{array}$ & $\begin{array}{l}\text { Iowa CRP fields } \\
{\text { (egg, nestling stage })^{\mathrm{d}}}^{\mathrm{egg}}\end{array}$ & $\begin{array}{l}\text { Restored } \\
\text { prairie (IL) }\end{array}$ & $\begin{array}{l}\text { Reclaimed coal } \\
\text { mines (IN) })^{\mathrm{f}}\end{array}$ \\
\hline Red-winged Blackbird & - & - & - & $0.943,0.916$ & 0.954 & 0.923 \\
\hline Eastern Meadowlark & - & 0.940 & - & - & 0.953 & 0.951 \\
\hline Dickcissel & 0.922 & 0.940 & - & $0.951,0.874$ & 0.941 & 0.903 \\
\hline Field Sparrow & - & - & 0.919 & - & 0.955 & 0.919 \\
\hline Grasshopper Sparrow & - & 0.930 & - & $0.957,0.937$ & 0.913 & 0.961 \\
\hline Henslow's Sparrow & - & 0.950 & 0.947 & - & - & 0.949 \\
\hline
\end{tabular}

the idea that cowbirds in the eastern United States focus on forested habitats (Hahn and Hatfield 1995). Indeed, Brown-headed Cowbird is among the rarest passerine species inhabiting reclaimed coal mines in Indiana (DeVault et al. 2002).

Shrub/savanna species underwent greater rates of parasitism than grassland species (Table 3), but it was still much lower than that typically observed in forested habitats across Indiana and Illinois (e.g., Robinson et al. 1995). Among the focal savanna species (Table 1), only Yellow Warblers were parasitized to a substantial degree (Table 3). Note, however, that three of our focal savanna species are either inappropriate cowbird hosts (Mourning Doves) or egg rejectors (American Robins and Brown Thrashers). Parasitism appeared to be greater for some non-focal savanna species (e.g., Orchard Orioles and Blue Grosbeaks; Table 3), but we found too few nests to reach a conclusion concerning their susceptibility to parasitism. We suspect that greater rates of cowbird parasitism in our shrub/savanna sites reflected their proximity to forested habitat (Hahn and Hatfield 1995).

Conservation implications. - Our data suggest that reclaimed surface coal mines are no more likely to represent reproductive traps than are other habitats studied to date. We base this view on a comparison of our results with those from comparable studies across the midwestern United States. DNS within reclaimed coal mine grasslands at our study sites is broadly comparable to that in other midwestern grasslands (Table 4). The most comparable study is one that took place in large blocks of restored prairies in nearby eastern Illinois (Kershner 2001, Walk 2001). DNS of Eastern Meadowlarks in Illinois was essentially identical to that observed in our reclaimed mine sites (Table 4). Dickcissels and Field Sparrows experienced greater nest success at the Illinois sites than at our sites, whereas Grasshopper Sparrows experienced greater success at our mine sites (few Henslow's Sparrow nests were found at the Illinois site). Similar to what we found in our study, Red-winged Blackbirds in Conservation Reserve Program (CPR) fields of Iowa experienced poor to mediocre nesting success, Dickcissels experienced low success (with very low survival in the nestling stage), and Grasshopper Sparrows had relatively high rates of success (Patterson and Best 1996). Dickcissels also may not be doing well in Kansas or Missouri CRP fields (Hughes et al. 1999, Winter and Faaborg 1999). Nesting success of Field and Henslow's sparrows at the Big Oaks National Wildlife Refuge (formerly the Jefferson Proving Ground) in southeastern Indiana is virtually identical to that of birds nesting on reclaimed surface coal mines (Robb et al. 1998). Furthermore, survival estimates for Henslow's Sparrows across the three relevant studies (Robb et al. 1998, Winter and Faaborg 1999; this study) were remarkably similar and relatively high, indicating that this species is probably doing reasonably well where it is still nesting. Similarly, Monroe and Ritchison (2005) reported comparable levels of nesting success for Henslow's Sparrows on reclaimed mines and unmined grasslands in western Kentucky, and suggested that reclaiming surface mines could help stabilize the population decline of Henslow's Sparrows. We suspect that similar conclusions also could be drawn for some savanna species on reclaimed mines, but compara- 
ble data are not yet available with which to make analogous comparisons.

Reclaimed mines of the Midwest provide a unique opportunity in avian conservation, especially for the management of grassland birds. Many of the reclaimed mines are $>2,000$ ha, larger than most (if not all) remaining prairie fragments in Indiana and Illinois, and contain large populations of several bird species of concern (Bajema et al. 2001, DeVault et al. 2002, Ingold 2002). The nesting success of key species (e.g., Henslow's Sparrows and Grasshopper Sparrows) at these reclaimed mines is comparable with that in nonmined grassland habitats. A feature that should make reclaimed midwestern surface coal mines attractive from a management perspective is that they are usually owned by a single entity. Furthermore, most reclaimed mines are typically not very productive as agricultural areas. These factors combined make possible the acquisition or management of large grassland-dominated habitats. Few such opportunities currently exist in the eastern United States.

\section{ACKNOWLEDGMENTS}

The U.S. Fish and Wildlife Service, the U.S. Geological Survey, and the Ohio River Valley Ecosystem Group provided financial support for this project. We are grateful to the following individuals for allowing us full access to reclaimed mine properties: A. Eicher and S. McGarvie of Peabody Coal, R. Ronk of the Indiana Department of Natural Resources, M. Krieger at Universal Mine, and L. Nelson of the Midwest Coal Company. We also thank G. S. Bakken, M. T. Jackson, and P. E. Scott for valuable help and advice. Special thanks go to R. Gushee, J. Mozingo, C. Roever, B. Thomas, and A. Worthington for their competent fieldwork and keen nest-finding abilities. We are grateful to M. D. Carey and two anonymous reviewers for helpful comments that improved this manuscript.

\section{LITERATURE CITED}

Bajema, R. A., T. L. DeVault, P. E. Scott, and S. L. LiMA. 2001. Large reclaimed coal mine grasslands and their significance for Henslow's Sparrows in the American Midwest. Auk 118:422-431.

Bajema, R. A. AND S. L. LimA. 2001. Landscape-level analyses of Henslow's Sparrow (Ammodramus henslowii) abundance in large, reclaimed coal mine grasslands. American Midland Naturalist 145:288-298.

BART, J. 1977. Impact of human visitations on nesting success. Living Bird 16:187-192.
Best, L. B. 1978. Field Sparrow reproductive success and nesting ecology. Auk 95:9-22.

Best, L. B., H. Campa, III, K. E. Kemp, R. J. Robel, M. R. Ryan, J. A. SAVidge, H. P. WeEks, JR., AND S. R. Winterstein. 1997. Bird abundance and nesting in CRP fields and cropland in the Midwest: a regional approach. Wildlife Society Bulletin 25:864-877.

Brothers, T. S. 1990. Surface-mine grasslands. Geographical Review 80:209-225.

Burhans, D. E., D. Dearborn, F. R. Thompson, III, AND J. FAABORG. 2002. Factors affecting predation at songbird nests. Journal of Wildlife Management 66:240-249.

Clay, K. and J. Holah. 1999. Fungal endophyte symbiosis and plant diversity in successional fields. Science 285:1742-1744.

Clotfelter, E. D. and K. Yasukawa. 1999. Impact of brood parasitism by Brown-headed Cowbirds on Red-winged Blackbird reproductive success. Condor 101:105-114.

Davis, M. A., D. W. Peterson, P. B. Reich, M. CroZIER, T. Query, E. Mitchell, J. Huntington, AND P. BAZAKAS. 2000. Restoring savanna using fire: impact on the breeding bird community. Restoration Ecology 8:30-40.

DAvis, S. K. 2003. Nesting ecology of mixed-grass prairie songbirds in southern Saskatchewan. Wilson Bulletin 115:119-130.

DeVault, T. L., P. E. Scott, R. A. Bajema, and S. L. LiMA. 2002. Breeding bird communities of reclaimed coal-mine grasslands in the American Midwest. Journal of Field Ornithology 73:268275.

Donovan, T. M., F. R. Thompson, III, J. FAABORG, AND J. R. Probst. 1995. Reproductive success of migratory birds in habitat sources and sinks. Conservation Biology 9:1380-1395.

Galligan, E. W., G. S. BaKken, and S. L. Lima. 2003. Using a thermographic imager to find nests of grassland birds. Wildlife Society Bulletin 31:865869.

Gates, J. E. And L. W. Gysel. 1978. Avian nest dispersion and fledging success in field-forest ecotones. Ecology 59:871-883.

Hahn, D. C. AND J. S. Hatfield. 1995. Parasitism at the landscape scale: cowbirds prefer forest. Conservation Biology 9:1415-1424.

Herkert, J. R. 1994. The effects of habitat fragmentation on midwestern grassland bird communities. Ecological Applications 4:461-471.

Herkert, J. R., D. L. Reinking, D. A. Wiedenfeld, M. Winter, J. L. Zimmerman, W. E. Jensen, E. J. FincK, R. R. Koford, D. H. Wolfe, S. K. SherROD, ET AL. 2003. Effects of prairie fragmentation on the nest success of breeding birds in the midcontinental United States. Conservation Biology 17:587-594.

Hines, J. E. AND J. R. SAuer. 1989. Program CONTRAST: a general program for the analysis of several survival or recovery estimates. U.S. Fish and 
Wildlife Service, General Technical Report 24, Washington, D.C.

Horn, D. J., R. J. Fletcher, JR., AND R. R. Koford. 2000. Detecting area sensitivity: a comment on previous studies. American Midland Naturalist 144:28-35.

Hughes, J. P., R. J. Robel, K. E. Kemp, and J. L. ZiMMERMAN. 1999. Effects of habitat on Dickcissel abundance and nest success in Conservation Reserve Program fields in Kansas. Journal of Wildlife Management 63:523-529.

Hunter, W. C., D. A. Buehler, R. A. Canterbury, J. L. Confer, AND P. B. Hamel. 2001. Conservation of disturbance-dependent birds in eastern North America. Wildlife Society Bulletin 29:440-455.

INGOLD, D. J. 2002. Use of reclaimed stripmine by grassland nesting birds in east-central Ohio. Ohio Journal of Science 102:56-62.

Johnson, D. H. AND L. D. IGL. 2001. Area requirements of grassland birds: a regional perspective. Auk 118:24-34.

Johnson, R. G. And S. A. Temple. 1990. Nest predation and brood parasitism of tallgrass prairie birds. Journal of Wildlife Management 54:106-111.

KERSHNER, E. L. 2001. Conservation of grassland birds in an agricultural landscape: the importance of habitat availability and demography. Ph.D. dissertation, University of Illinois, Urbana-Champaign.

Kershner, E. L. AND E. K. Bollinger. 1998. Low incidence of cowbird parasitism of grassland birds on Illinois airports. Transactions of the Illinois Academy of Science 91:103-107.

Maier, T. J. And R. M. DeGraAf. 2000. Rhodamineinjected eggs to photographically identify small nest-predators. Journal of Field Ornithology 71: 694-701.

Martin, T. E. AND G. R. Geupel. 1993. Nest-monitoring plots: methods for locating nests and monitoring success. Journal of Field Ornithology 64: 507-519.

MAYFiELD, H. 1961. Nesting success calculated from exposure. Wilson Bulletin 73:255-261.

MAYFIELD, H. 1975. Suggestions for calculating nest success. Wilson Bulletin 87:456-466.

Monroe, M. S. AND G. Ritchison. 2005. Breeding biology of Henslow's Sparrows on reclaimed coal mine grasslands in Kentucky. Journal of Field Ornithology 76:143-149.

NoRUŠIS, M. J. 1993. SPSS for Windows: base system user's guide, release 6.0. SPSS Inc., Chicago, Illinois.

PAton, P. W. C. 1994. The effect of edge on avian nest success: how strong is the evidence? Conservation Biology 8:17-26.

Patterson, M. P. And L. B. Best. 1996. Bird abundance and nesting success in Iowa CRP fields: the importance of vegetation structure and composition. American Midland Naturalist 135:153-167.

PicozZI, N. 1975. Crow predation on marked nests. Journal of Wildlife Management 39:151-155.
Pietz, P. J. And D. A. Granfors. 2000. Identifying predators and fates of grassland passerine nests using miniature video cameras. Journal of Wildlife Management 64:71-87.

PRIBIL, S. 1998. Reproductive success is a misleading indicator of nest-site preferences in the Redwinged Blackbird. Canadian Journal of Zoology 76:2227-2234.

Robb, J. R., S. A. Miller, T. Vanosdol-Lewis, And J. P. LEWIS. 1998. Productivity of interior forest and grassland birds on Jefferson Proving Ground: 1998 annual report. U.S. Fish and Wildlife Service, Jefferson Proving Ground, Madison, Indiana.

Robinson, S. K. AND J. L. Herkert. 1997. Cowbird parasitism in different habitats. Illinois Natural History Reports 348:2-3.

Robinson, S. K., F. R. Thompson, III, T. M. Donovan, D. R. Whitehead, AND J. FAaborg. 1995. Regional forest fragmentation and the nesting success of migratory birds. Science 267:1987-1990.

SAuER, J. R. AND B. K. Williams. 1989. Generalized procedures for testing hypotheses about survival or recovery rates. Journal of Wildlife Management 53:137-142.

Scott, P. E., T. L. DeVault, R. A. Bajema, and S. L. LiMA. 2002. Grassland vegetation and bird abundances on reclaimed midwestern coal mines. Wildlife Society Bulletin 30:1006-1014.

ScotT, P. E. AND S. L. Lima. 2004. Exotic grasslands on reclaimed midwestern coal mines: an ornithological perspective. Weed Technology 18:15181521.

Thompson, F. R., III, W. DiJAK, AND D. E. Burhans. 1999. Video identification of predators at songbird nests in old fields. Auk 116:259-264.

WALK, J. W. 2001. Nesting ecology of grassland birds in an agricultural landscape. Ph.D. dissertation, University of Illinois, Urbana-Champaign.

WALK, J. W. AND R. E. WARNER. 1999. Effects of habitat area on the occurrence of grassland birds in Illinois. American Midland Naturalist 141:339344.

WARNER, R. E. 1994. Agricultural land use and grassland habitat in Illinois: future shock for midwestern birds? Conservation Biology 8:147-156.

WinTER, M. 1999. Nesting biology of Dickcissels and Henslow's Sparrows in southwestern Missouri prairie fragments. Wilson Bulletin 11:515-527.

Winter, M. AND J. FAABORG. 1999. Patterns of area sensitivity in grassland-nesting birds. Conservation Biology 13:1424-1436.

Winter, M., D. H. Johnson, And J. FAaborg. 2000. Evidence for edge effects on multiple levels in tallgrass prairie. Condor 102:256-266.

Winter, M., D. H. Johnson, J. A. Shaffer, AND W. D. SVEDARSKY. 2004. Nesting biology of three grassland passerines in the northern tallgrass prairie. Wilson Bulletin 116:211-223.

Yasukawa, K. AND W. A. Searcy. 1995. Red-winged Blackbird (Agelaius phoeniceus). The Birds of North America, no. 184. 